\title{
Expression of Hoxa1 and Hoxd3 genes in chicken embryos with exencephaly*
}

\author{
K. Jaszczak ${ }^{1,3}$, T. Malewski ${ }^{1}$, R. Parada ${ }^{1}$ and H. Malec ${ }^{2}$ \\ ${ }^{1}$ Institute of Animal Genetics and Breeding, Polish Academy of Sciences \\ Jastrzębiec, 05-552 Wólka Kosowska, Poland \\ 2"MALEC" Hatchery \\ Dębówka 1a, 05-530 Góra Kalwaria, Poland
}

(Received 2 January 2006; revised version 23 March 2006; accepted 5 July 2006)

\begin{abstract}
Analysis of skeletal malformations in embryos that died between day 17 and 21 of incubation obtained from two reproductive flocks of broiler chickens showed exencephaly to be the most common defect. It comprises about $48 \%$ of all diagnosed axial skeleton disorders. Analysis of the expression of Hoxa1 and Hoxd3 genes by real time PCR revealed upregulation of Hoxa1 in chicken embryos with exencephaly (16.8-fold higher), when compared with healthy birds. Upregulation of Hoxa1 suggests that this gene may be associated with exencephaly in chickens.
\end{abstract}

KEY WORDS: homeobox genes, exencephaly, chicken embryos

\section{INTRODUCTION}

Skeletal problems are very common in chickens and comprise many different disorders affecting skeletal, muscular and nervous systems (Riddell, 1981; Day, 1990). These disorders cause considerable losses in breeding poultry as they lead to the culling of birds and increased mortality (Sulivan, 1994).

Skeletal disorders may be caused by multiple factors and their etiology is still poorly defined. Many reports emphasize genetic and nutritional factors as their principal causes (Wise, 1973; Morris, 1993).

\footnotetext{
* Supported by the State Committee for Scientific Research, Grant No. 3P06D00523

${ }^{3}$ Corresponding author: e-mail: K.Jaszczak@ighz.pl
} 
One of the frequent axial skeleton defects in chickens is exencephaly. Its expression ranges from the scarcely noticeable hydrencephalocele to massive herniation. The basic defect is cranioschisis with extrusion of the brain (Somes, 1990). This defect may be caused by a recessive gene with incomplete penetration, but its exact mode of inheritance is not yet known. Polygenic inheritance may also be involved (Mellen, 1959).

One of the groups of genes regulating craniofacial development is the homeobox genes, representing a family of evolutionarily highly conserved transcription factors. Tetrapod vertebrates possess 39 Hox genes, arranged in 4 separate, but homologous clusters, named A, B, C, and D. During embryogenesis Hox genes are expressed along the anterior-posterior (A-P) axis in the same order in which they occur on the chromosome (Gaunt, 1991). The murine Hoxal gene is a member of the vertebrate Hox complex and plays a role in defining the body plan during development. On day 8.0-9.0 post coitus, Hoxal transcripts are detected extensively throughout the embryo in the neural tube, adjacent mesenchyme, paraxial mesoderm, somites and gut epithelium; its expression extends from the most caudal region of the embryo to the rhombomere $3 / 4$ border (Ladjali-Mohammedi et al., 2001). This spatiotemporal expression of Hoxal mRNA is critical for normal embryonic development (Thompson et al., 1998). A knockout of the Hoxa3 gene in the mouse produces a phenotype similar to the DiGeorge syndrome in the human (Chisaka and Capecchi, 1991). Yueh et al. (1998) showed that overexpression of a Hoxc8 transgene causes cartilage defects and their severity depends on the transgene dosage. The abnormal cartilage is characterised by accumulation of proliferating chondrocytes and reduced maturation. Burke et al. (1995) reported expression of 23 Hox genes during the early development of chickens. However, the expression of these genes is not limited to embryonic stages of development and also continues in the postnatal period (Bomgardner et al., 2001; Komuves and Largman, 2005).

Although the chicken genome has been fully sequenced (Hillier et al., 2004) not all Hox cluster genes were annotated. For the present investigations the three most proximal genes in the Hox gene cluster were taken into consideration. The aim of the current study was to compare the expression of the Hoxa1 and Hoxd3 genes in chicken embryos with exencephaly with that in normal embryos.

\section{MATERIAL AND METHODS}

\section{Animals and tissues}

The incidence of axial skeleton defects was dissectionally determined in 10540 embryos that died between day 17 and 21 of incubation. The eggs were obtained from 
two reproductive flocks of broiler chickens (Cobb and Ross). For further studies, eight dead chicken embryos with exencephaly were selected on day 21 of incubation. Exencephalic chickens showed a deficiency of cranial bones in the frontoparietal region with extrusion of the brain (Figure 1). The control group consisted of eight chicken embryos without skeletal malformations that were in the same stage of development. The heads of those chicks were detached, cleared from skin and connective tissues and frozen at $-70^{\circ} \mathrm{C}$ for further analysis.

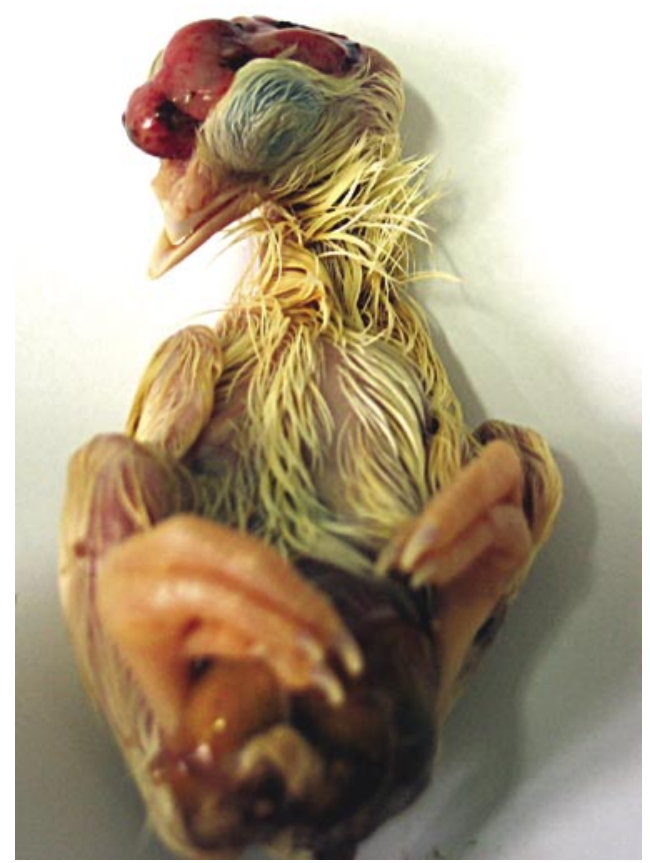

Figure 1. Chicken embryo with exencephaly 20/21 day of incubation

RNA extraction. Total RNA from frozen head tissues was extracted with TRI Reagent (Sigma-Aldrich, Inc.) according to the manufacturer's protocol. Briefly, up to $0.5 \mathrm{~g}$ of frozen tissue was homogenised in $5 \mathrm{ml}$ of TRI Reagent. Next, 1 $\mathrm{ml}$ of chloroform was added, shaken vigorously and incubated $15 \mathrm{~min}$ at room temperature. The obtained mixture was centrifuged at $12000 \mathrm{~g}$ for $15 \mathrm{~min}$ at $4^{\circ} \mathrm{C}$. The aqueous phase was collected and transferred to a fresh tube. Isopropanol $(0.5 \mathrm{ml}$ per ml of TRI Reagent) was added and the mixture was incubated for $10 \mathrm{~min}$ at room temperature. Next, the precipitate was centrifuged and RNA pellet was washed with $75 \%$ ethanol. RNA integrity was electrophoretically verified on agarose gel. 


\section{$R T-P C R$}

For elimination of probe contamination by genomic DNA the total RNA was treated with RNase-free DNase I (Sigma-Aldrich, Inc.) - $1 \mu \mathrm{g}$ of RNA was treated with $1 \mathrm{U}$ of DNase I for $15 \mathrm{~min}$ at room temperature. The reaction was stopped by adding a stop solution (50 mM EDTA) and DNase was inactivated at $70^{\circ} \mathrm{C}$ for $10 \mathrm{~min}$. The reverse transcription was carried out using an Enhanced Avian HS RT-PCR Kit (Sigma - Aldrich, Inc.) according to the manufacturer's protocol. One $\mu \mathrm{g}$ of anchored oligo $(\mathrm{dT})_{23}$ primer was annealed to a mixture containing $1 \mu \mathrm{g}$ of DNase-treated RNA. Following $10 \mathrm{~min}$ of incubation at $70^{\circ} \mathrm{C}$, all components [dNTP $(10 \mathrm{mM}$ dATP, $10 \mathrm{mM}$ dCTP, $10 \mathrm{mM}$ dGTP, $10 \mathrm{mM}$ dTTP), $20 \mathrm{U}$ RNase inhibitor, $20 \mathrm{U}$ Enhanced Avian Reverse Transcriptase, 10 x buffer eAMV-RT (500 mM Tris- $\mathrm{HCl}$ pH8.3, $400 \mathrm{mM} \mathrm{KCl}, 80 \mathrm{mM} \mathrm{MgCI}, 10 \mathrm{mM} \mathrm{DTT}$ ) and water] were added and the reaction was carried out at $45^{\circ} \mathrm{C}$ for $50 \mathrm{~min}$. The cDNA was used immediately in the PCR or stored at $-20^{\circ} \mathrm{C}$. The RT-PCR reaction was repeated 3 times for each RNA probe.

Primers for the Hoxal gene were derived from the chicken sequence (GenBank Acc. No. AY188521.1). The primer design was obtained using Primer 3 software. The forward primer is located in position 25 (5'-CCCTCCAGCTCAACGAGAC-3') and the reverse (5'-GACGGGCA GCACTTCTCC-3'), in position 181 of the chicken Hoxal gene. The amplified cDNA was $156 \mathrm{bp}$ long (the exon-intron of this gene structure has not yet been described).

Primers for the Hoxd3 gene were derived from the chicken sequence (GenBank Acc. No. AF067959.1). The forward primer is located in position 2215 (5'-CAGGGCAAGCATCCTCTAAG-3') and the reverse (5'-TGCCCTTTTGATCCTTTTTG-3'), in position 2415 of the chicken Hoxd3 gene. The amplified cDNA was 200 bp long in the second exon of Hoxd3.

The expression of the genes Hoxal and Hoxd3 was normalized to the expression of the osteopontin gene. Osteopontin is a major noncollagenous component of bone and is the major phosphoprotein synthesised by cultured chicken embryo osteoblasts (Moore et al., 1991). This gene was chosen to measure the amount of bone and cartilage in a tissue probe. Tissues were collected from healthy and sick chickens at the some period of development, so as not to search for a gene with constitutive expression over an extensive period of bone and cartilage development. Primers for the osteopontin gene were derived from the chicken sequence (GenBank Acc. No. M59182.1). The forward primer is located in position 306 (5'-TCCTAGCAAGAGCCAAGAGG-3') and the reverse (5'-GCCATATGCCACACTGTCAC -3'), in position 471 of the chicken osteopontin gene. The amplified cDNA was 165 bp long (exons six and seven).

Real-time PCR was performed using a LightCycler (Roche). Amplification mixtures $(20 \mu \mathrm{l})$ contained $2 \mu \mathrm{l}$ RT product, $10 \mu \mathrm{l}$ SYBR Green JumpStart Taq 
Ready Mix Capillary Formulation (Sigma-Aldrich), $2 \mu \mathrm{l} 5 \mathrm{mM}$ of forward and reverse primer and $4 \mu \mathrm{l}$ of water. The following reaction conditions were applied: denaturation for $5 \mathrm{~min}$ at $95^{\circ} \mathrm{C}$; amplification for 40 cycles, with denaturation for $0 \mathrm{~s}$ at $95^{\circ} \mathrm{C}$, annealing for $10 \mathrm{~s}$ at $55^{\circ} \mathrm{C}$ and extension for $15 \mathrm{~s}$ at $72^{\circ} \mathrm{C}$. A melting curve analysis was performed from 65 to $95^{\circ} \mathrm{C}$. Fragments of Hoxa1, Hoxd3 and osteopontin genes amplified by conventional PCR were used as standards. Their concentrations were measured on a Beckman DU68 spectrophotometer.

\section{RESULTS AND DISCUSSION}

The analysis covered a total of 10540 dead embryos over two reproductive seasons (Table 1). The obtained results demonstrate that exencephaly constituted the

Table 1. The incidence of skeletal defects in dead chicken embryos $(n=10540)$

\begin{tabular}{lcc}
\hline Skeletal defect & $\begin{array}{c}\text { Chicken embryos } \\
\text { with defects, } \%\end{array}$ & $\begin{array}{c}\text { Ratio of particular } \\
\text { defects/total }\end{array}$ \\
\hline Exencephaly & $123(1.17)$ & 0.48 \\
Scoliosis & $32(0.30)$ & 0.13 \\
Crooked neck & $31(0.29)$ & 0.12 \\
Cyclopia & $11(0.10)$ & 0.04 \\
Supernumerally legs & $17(0.16)$ & 0.07 \\
Disorders of beak & $42(0.40)$ & 0.16 \\
Total & $256(2.42)$ & \\
\hline
\end{tabular}

major type of axial skeleton malformation (48.04\% of all axial skeleton defects) in embryos dead before hatching. In the studied chicken flocks, this skeletal defect was not observed in live hatched chickens. It is probable that the deficiency of covering cranial bones (frontal bone, parietal bone) makes it impossible for the chicken to perforate the egg shell and hatch. Among all skeletal defects, the next most frequent were beak defects (16\%), scoliosis $(13 \%)$ and crooked neck (12\%).

The expression of Hoxa1 and Hoxd3 genes was estimated both in healthy chicken embryos and in those with exencephaly. The RNA isolated from four heads and four chickens with skeletal malformations was pooled to avoid individual differences in the transcription level of the examined genes. Thus the cDNA was synthesized and Real Time PCR was performed on pooled samples of RNA. Both

Table 2. Relative expression of Hoxa1 and Hoxd3 genes in chickens. Expression of Hoxa1 and Hoxad3 genes was normalized against osteopontin gene expression

\begin{tabular}{lcc}
\hline Gene & Healthy chickens & Chickens with exencephaly \\
\hline Hoxa1/osteopontin & 2.2 & 36.9 \\
Hoxd3/osteopontin & 0.9 & 1.1 \\
\hline
\end{tabular}


reactions were performed three times. The results of the RT-PCR analysis of the expression of Hox genes are presented in Table 2. The expression of Hoxa1, the most proximal gene in the Hox cluster, was strongly upregulated (16.8fold), while the expression of Hoxd3, the third gene in the Hox cluster, showed no differences between healthy chicken embryos and chicken embryos with exencephaly. Unfortunately, the sequence of genes Hoxb1, Hoxc1 and Hoxd1 are not yet available and thus the measurement of their expression was not possible.

The vertebrate head is a composite structure and its formation begins early in embryo development, when the brain is beginning to form. Central to the development of a head is the concept of segmentation, manifest in the hindbrain and branchial arch systems. In conjunction with migrating neural crest cells, these systems give rise to much of the head and neck and their associated individualized compartments. The expression of Hox genes in the vertebrate embryo can be seen along the dorsal axis within the CNS, from the anterior region of the hindbrain through the length of the spinal cord. The patterns of expression of these genes show very precise spatial restriction. Each Hox gene is expressed in an overlapping domain, along the anterior-posterior axis of the embryo, but each gene has a characteristic segmental limit of expression at its anterior boundary. In the developing head, this spatially restricted expression pattern is seen in the hindbrain with the anterior limits of Hox gene expression, corresponding to rhombomere boundaries at two-segment intervals. As the neural crest migrates from the rhombomeres into specific branchial arches it retains the particular combination, or code of Hox gene expression, that is characteristic of the rhombomeres from which it originated (Cobourne and Ort, 2000). Recently, the participation of Hox genes in cranial skeleton development was reported for the chicken (Couly et al., 2002). The results of the present investigations indicate that Hoxal may be one of the genes associated with the development of exencephaly in chicken embryos.

\section{REFERENCES}

Bomgardner D., Hinton B.T., Turner T.T., 2001. Hox transcription factors may play a role in regulating segmental function of the adult epidymis. J. Andrology 4, 527-531

Burke A.C., Nelson C.E., Morgan B.A., Tabin C., 1995. Hox genes and the evolution of vertebrate axial morphology. Development 121, 333-346

Chisaka O., Capecchi M.R., 1991. Regionally restricted developmental defects resulting from targeted disruption of the mouse homeobox gene hox-1.5. Nature 350, 473-479

Cobourne M.T., Ort M., 2000. Construction for the Modern Head: current concepts in craniofacial development. J. Orthodont. 27, 307-314

Couly G., Creuzet S., Bennaceur B., Vincent Ch., Le Douarin N.M., 2002. Interactions between Hox-negative cephalic neural crest cells and the foregut endoderm in patterning the facial skeleton in the vertebrate head. Development 129, 1061-1073 
Day E.J., 1990. Future research needs focus on new, old problems. Feedstuffs 62 (23), 12-15

Gaunt S.J., 1991. Expression patterns of mouse Hox genes: clues to an understanding of developmental and evolutionary strategies. Bioessays 13, 505-513

Hillier L.W. et al., 2004. The chicken genome sequencing consortium, sequence and comparative analysis of the chicken genome provide unique perspectives on vertebrate evolution. Nature $432,695-716$

Komuves L.G., Largman C., 2005. Analysis of Hox homeodomain proteins and gene transcripts in the epidermis. Methods Mol. Biol. 289, 157-170

Ladjali-Mohammedi K., Grapin-Botton A., Bonnin M.A., Le Douarin N.M., 2001. Distribution of Hox genes in the chicken genome reveals a new segment of conservation between human and chicken. Cytogenet. Cell Genet. 92, 157-61

Mellen W.J., 1959. Hereditary exencephaly in the fowl. J. Heredity 50, 127-130

Moore M.A., Gotoh Y., Rafidi K., Gerstenfeld L.C., 1991. Characterization of a cDNA for chicken osteopontin: expression during bone development, osteoblast differentiation, and tissue distribution. Biochemistry 30, 2501-2508

Morris M.P., 1993. National survey of leg problems. Broiler Ind. 5, 20-24

Riddell C., 1981. Skeletal deformities in poultry. Adv. Vet. Sci. Comp. Med. 25, 277-310

Somes R.G., 1990. Mutations and major variants of muscles and skeleton in chickens. In: R.D. Crawford (Editor). Poultry Breeding and Genetics. Elsevier, Amsterdam, pp. 209-237

Sulivan T.W., 1994. Skeletal problems in poultry: estimated annual cost and descriptions. Poultry Sci. $73,879-82$

Thompson J.R., Chen S.W., Ho L., Langston A.W., Gudas L.J., 1998. An evolutionary conserved element is essential for somite and adjacent mesenchymal expression of the Hoxal gene. Develop. Dynam. 211, 97-108

Wise D.R., 1973. The incidence and aetiology of avian spondylolisthesis (kinky back). Res. Vet. Sci. 14, 1-10

Yueh Y.G., Gardner D.P., Kappen C., 1998. Evidence for regulation of cartilage differentiation by the homeobox gene Hoxc-8. Proc. Nat. Acad. Sci. USA 95, 9956-9961 